\title{
A hope for the reefs
}

\author{
John R. Pringle
}

Received: 20 July 2012 / Accepted: 8 August 2012 /Published online: 1 September 2012

(C) Springer Science+Business Media B.V. 2012

On coral reefs the world around,

Most wondrous creatures do abound.

How sad it is to have to say,

This spectacle may go away.

Reefs are built by coral polyps,

Bit by bit in tiny dollops.

And then provide a 3-D home

For those who in the sea do roam.

The polyps live in water clear,

So one might think starvation's near.

Nematocysts are set to shoot,

But without prey, harpoons are moot.

Yet thrust for growth and building comes

From photosynth that really hums.

The dinoflagellates inside

Pump ATP through every tide.

A mutualism co-evolved,

Cohabitation's problems solved.

But now the reefs are prone to bleach,

No site is safe, beyond man's reach.

And those who live upon the reef

From greenhouse gases come to grief.
Temperature rises, $\mathrm{pH}$ falls,

The ROS release then galls.

Too common now, the coral head With symbionts expelled or dead.

Less production, fewer niches;

Catastrophic system switches.

But can we save them? That's not clear.

The time is short, research is dear.

The underfunded science slows,

While every day the danger grows.

To save the reefs we need to know

Just how their cells divide and grow.

But corals in the lab are hard,

With features that research retard.

Luckily we have Aiptasia,

Model system to amaze ya.

Experiments with it we'll do

That insights give both deep and true.

And then we can to reefs return,

Their secrets better now to learn.

With knowledge we may dodge the worst, And by the future not be cursed!

J. R. Pringle $(\bowtie)$

Stanford University School of Medicine,

Stanford, CA, USA

e-mail: jpringle@stanford.edu 


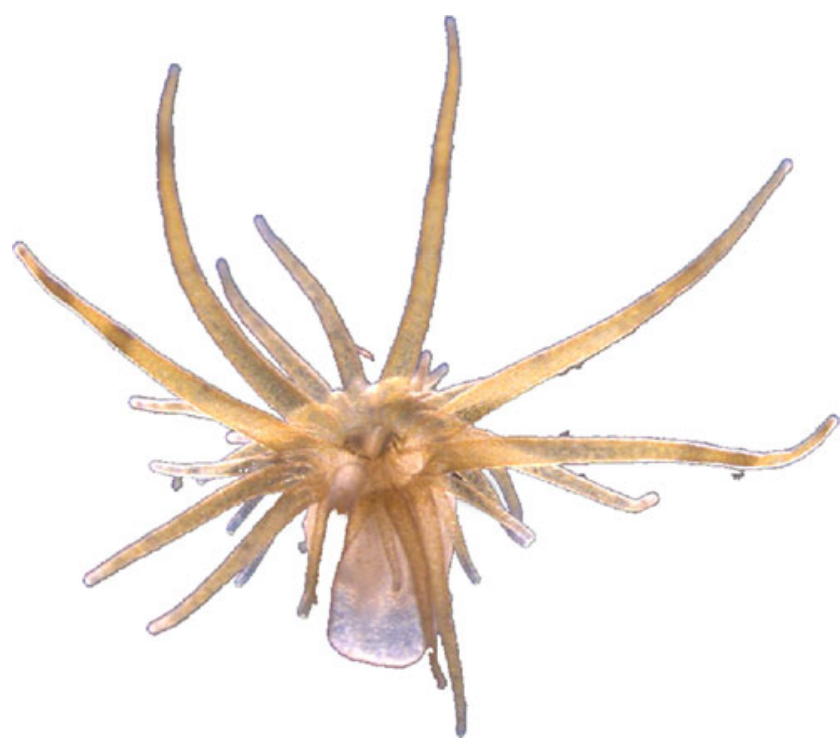

Fig. 1 Bright-field stereomicroscope image of a polyp of the sea anemone Aiptasia pallida; background has been subtracted for greater clarity (photo courtesy of Jan DeNofrio and Annika Guse)

Poetry is not the usual means of communication between scientists and their colleagues or between them and the general public. Nonetheless poems can be a powerful tool. For example, the current worldwide interest in dinosaurs was at least in part inspired by the poem 'Behold the mighty dinosaur' published in the Chicago Tribune by Bert L. Taylor and later included in the classic book Man and the Invertebrates, p. 92-3 by Alfred Sherwood Romer (1933) University of Chicago Press. Third edition of this book was

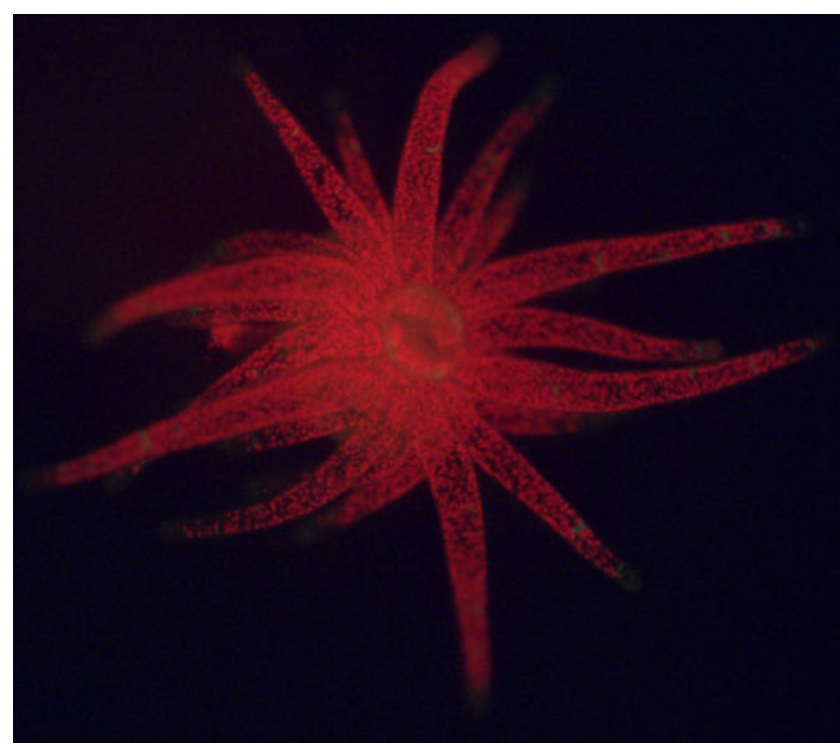

Fig. 2 Fluorescence stereomicroscope image of an Aiptasia polyp. Red shows the chlorophyll fluorescence from the Symbiodinium dinoflagellates; green shows the fluorescence from an unidentified compound that (surprisingly) does not seem to be a green fluorescent protein like those found in many other cnidarians (photo courtesy of Liz Hambleton)

reguired reading for a generation of biology students in America and the United Kingdom in the 1960s and 1970s. Having been part of that generation, I am happy to accept the following poem for publication in Symbiosis and hope that it too has a wide circulation as it carries an important message.

David H.S. Richardson

Editor in Chief 